\title{
Hypogeous Fungi Occurrence, Distribution AND MYCORRHIZAL HoSTS in Grand Teton National Park AND John D. Rockefeller, Jr. Memorial PARKWAY
}

\author{
STEVEN L. MiLLER \\ DEPARTMENT OF BOTANY — UNIVERSITY OF WYOMING \\ LARAMIE
}

\section{$\downarrow$ ObJectives}

The 1990 field season constituted the last of a three year study to survey the hypogeous fungi of Grand Teton National Park and the Greater Yellowstone ecosystem. The objectives were to:

1. collect and identify hypogeous fungi found in association with ectomycorrhizal tree hosts such as lodgepole pine (Pinus contorta), subalpine fir (Abies lasiocarpa), Douglas-fir (Pseudotsuga menziesii), quaking aspen (Populus tremuloides), and speckled alder (Alnus tenuifolia), and several species of willow (Salix sp.) throughout the area; and

2. to gain an initial understanding of the importance of these fungi as food for small mammals.

\section{$\downarrow \quad$ MethodS}

Both objectives were addressed by collecting sporocarps of hypogeous fungi with a handheld truffle rake several times during the growing season. Collecting sites in pure or mixed stands of the ectomycorrhizal tree hosts were located away from high visibility areas, so as not to spoil the aesthetic appeal of the area. Litter duff and soil were carefully replaced after each collection, in an attempt to minimize disturbance of the soil. Each collection was photographed, described in detail, and dried in the field with silica gel for additional study.

\section{$\downarrow \quad$ Results}

Since the inception of the study in 1988, several new records for Grand Teton National Park have been found (Miller 1989, McKnight 1982, McKnight et al. 1990), as well as one or two probable undescribed species. 
The following hypogeous fungi and associated hosts were reported during 1990:

\author{
Engelmann spruce \\ Gautieria monticola (Harkn.) Harkn. \\ Subalpine fir \\ Thaxterogaster pingue (Zeller) Singer \& \\ Smith \\ Mixed spruce-fir \\ Geopora cooperi Harkn. \\ Leucogaster rubescens Zeller \& Dodge \\ Lodgepole pine \\ Brauniellula nanceyae Smith \\ Endogone lactiflua Berk. \& Broome \\ Rhizopogon ochraceorubens A. H. Smith \\ Rhizopogon rubescens var. rileyi Smith \\ Willow \\ Rhizopogon subcaerulescens A. H. Smith \\ Hymenogaster sp. \\ Tuber sp. \\ Alder \\ Alpova diplophloeus (Zeller \& Dodge) Trappe \\ \& Smith
}

\section{$\downarrow \quad$ Conclusions}

Adequate moisture is a prerequisite for fungal fruiting, even for hypogeous fungi which may be adapted to more arid environments. The field seasons of 1988 and 1989 were extremely dry in the northwest corner of Wyoming but even so, many collections of hypogeous fungi were made, with a number of new records for the area. The 1990 field season had only slightly more precipitation and several more records and perhaps two new species were collected. A study such as this could potentially be continued for a lifetime, with new fungi being found nearly every year. Collecting will be continued in the Greater Yellowstone area, as time and precipitation permit with the purpose of uncovering new species and new records.

\section{Literature Cited}

McKnight, K. H. 1982. Check-list of mushrooms and other fungi of Grand Teton and Yellowstone National Park. Moran, Wyoming, UW-NPS Research Center. 21 pp.

McKnight, K. H., M. M. Moser, H. D. Thiers and J. F. Ammirati. 1990. Taxonomy and ecology of ectomycorrhizal macrofungi of Grand Teton National Park. Ann. Rept. UW-NPS Res. Cent. 13:106-110.

Miller, S. L. 1989. Hypogeous fungi occurrence, distribution and mycorrhizal hosts in Grand Teton National Park and John D. Rockefeller, Jr. Memorial Parkway. Ann. Rept. UW-NPS Res. Cent. 12:107-108. 